Article

\title{
China's Energy Intensity, Determinants and Spatial Effects
}

\author{
Lei Jiang ${ }^{1, *}$ and Minhe $\mathrm{Ji}^{2}$ \\ 1 School of Economics, Zhejiang University of Finance and Economics, Hangzhou 310018, China \\ 2 The Research Center for East-West Cooperation in China, The Key Lab of GIScience of the Education \\ Ministry PRC, East China Normal University, Shanghai 200062, China; mhji@geo.ecnu.edu.cn \\ * Correspondence: lei_jiang@zufe.edu.cn; Tel.: +86-571-8673-5886
}

Academic Editor: Vincenzo Torretta

Received: 1 April 2016; Accepted: 7 June 2016; Published: 9 June 2016

\begin{abstract}
In the shadow of the energy crisis and environmental degradation, energy intensity is a hot topic in academic circles in China. The energy intensity distribution map of China indicates the fairly large geographic disparities globally and clustering locally in some areas, ascending from the southeast regions to the northwest provinces. Although energy intensity and its determinants vary from place to place, few studies have been made from the spatial perspective. Determinates of energy intensity and spatial spillover effects should be taken into consideration. Controlling for seven exogenous variables (per capita GDP; the share of the secondary sector; foreign direct investment; international trade, energy price, the share of coal, and transport sector) and their spatial lags, we apply a spatial Durbin model to test for spatial spillover effects among energy intensity and exogenous variables from a panel of 29 Chinese provinces over 1998 to 2014. We find that per capita GDP has an insignificant and negative direct and indirect effect, but has a significant and negative total effect on energy intensity. The share of the secondary sector and the share of coal are found to have significant and positive direct and indirect effects on energy intensity. Foreign Direct Investment (FDI) and Trade have significant and negative direct and indirect effects on energy intensity. The direct effect of energy price is found to be significantly positive while the indirect effect is negative. Only the direct effect of the Transport variable is significant and positive. The results of this study offer some theoretical evidence for differential localized policy making related to reduction in energy intensity.
\end{abstract}

Keywords: energy intensity; determinants; spatial Durbin model; panel data; China

\section{Introduction}

The Chinese economy has been experiencing rapid growth since 1978, when China started its nationwide economic reforms and opening up policy. This spectacular economic growth is accompanied by equally unprecedented energy consumption. In 2001, China's total energy consumption outpaced energy production. Finally, in 2009, China became the biggest energy consumer all over the world.

Behind this figure is a series of energy-related economic and environmental problems [1]. The Chinese central government is facing two severe challenges: energy shortage and environmental degradation. The only solution to these two issues is to intensively reduce China's energy intensity. Reduction in energy intensity means improvements of energy efficiency, leading to mitigating energy crisis and declining pollutant emissions. Therefore, energy intensity has become a vital and strategic problem for China's long-term sustainable development [2]. In its 11th Five-Year Plan (2006-2010) [3], for the first time China has carried out a mandatory domestic target, which aimed to achieve energy intensity reduction by $20 \%$ from the 2005 benchmark [4]. In the 12th Five-Year Plan (2011-2015) [5], the goal was given even greater emphasis by setting the target to a $16 \%$ further reduction. This national 
priority is further signified by the fact that energy efficiency improvement has been listed as one of the major performance criteria to evaluate provincial local governments. It is therefore crucial to explore how relevant factors may affect the energy intensity in China.

A large number of empirical studies on energy intensity consider a variety of important factors [6-8]; however, few however touch upon spatial spillover effects. Most of the studies employed classical econometric methods. Few studies on determinants of China's energy intensity have, however, been performed, especially from a spatial perspective. One exception is Yu [9], who uses a spatial panel data model to explore China's provincial energy intensity. He considers two kinds of spatial panel model specifications, namely, spatial lag model and spatial error model, but ignores another important model specification: spatial Durbin model. Spatial Durbin model specification takes both exogenous variables and spatially lagged exogenous variables as explanatory variables on the right hand side of the regression equation. Greene [10] asserts that if one or more relevant explanatory variables are ignored from a model specification, the biased and inconsistent estimator of the coefficients for the remaining variables results. In addition, $\mathrm{Yu}$ [9] also ignores spatial spillover effects of exogenous variables that play a crucial role in reducing energy intensity in China. Most importantly, there is a high probability that spatial spillover effects exist among Chinese provinces. If they are not considered in the regression model, biased conclusions may result. Spatial spillover effects could be used to reduce energy intensity and improve environmental quality. Controlling for spatially lagged exogenous variables, we therefore employ the spatial Durbin model in this study.

The objective of this paper is to use the spatial Durbin model to empirically analyze the determinants of energy intensity and their spatial spillover effects in China. The structure of the paper is as follows. Section 2 presents methods and introduces variables chosen in this study as well as data sources. Section 3 discusses our empirical results. Section 4 concludes as well as provides energy policies related to improvements of energy intensity and environmental protection.

\section{Methods and Variables}

\subsection{Methods}

Analysis of the determinants of energy intensity is based on the following model applied by Yuxiang and Chen [11], Herrerias et al. [8] and Sadorsky [12]:

$$
\begin{aligned}
\operatorname{Ln}(E I)_{i t} & =\alpha+\beta_{1} \operatorname{Ln}(G D P)_{i t}+\beta_{2} \operatorname{Ln}(\text { Second })_{i t}+\beta_{3} \operatorname{Ln}(F D I)_{i t}+\beta_{4} \operatorname{Ln}(\text { Trade })_{i t} \\
& +\beta_{5} \operatorname{Ln}(\text { Price })+\beta_{6} \operatorname{Ln}(\text { Coal })+\beta_{7} \operatorname{Ln}(\text { Transport })+\varepsilon_{i t}
\end{aligned}
$$

where the subscript $i$ represents province $i(i=1,2, \ldots, \mathrm{N})$, and $t$ denotes time $t(t=1,2, \ldots, \mathrm{T}) . \alpha$ is the constant term and $\varepsilon$ is the error term. Ln denotes natural logarithm. $E I$, as the dependent variable, denotes energy intensity while GDP, Second, FDI, Trade, Price, Coal, and Transport are exogenous variables that will be introduced in detail later (see Section 2.2).

\subsubsection{Spatial Econometric Model}

We are beginning to see an increase in spatial analysis incorporated into energy economic models. Studies cover patterns of energy use across space, spatial linkages between energy and the environmental pollutions as well as spatial spillovers in regional energy intensity, etc. $[9,13,14]$. We take into consideration spatial factors in our analysis as well. Below, spatial models are introduced [15]. 


\subsubsection{Spatial Lag Model}

The spatial lag model contains spatially lagged dependent variable. The formula is presented below:

$$
\begin{aligned}
\operatorname{Ln}(E I)_{i t} & =\rho \sum_{j=1}^{N} w_{i j} \operatorname{Ln}(E I)_{i t}+\beta_{1} \operatorname{Ln}(G D P)_{i t}+\beta_{2} \operatorname{Ln}(\text { Second })_{i t}+\beta_{3} \operatorname{Ln}(F D I)_{i t}+\beta_{4} \operatorname{Ln}(\text { Trade })_{i t} \\
& +\beta_{5} \operatorname{Ln}(\text { Price })+\beta_{6} \operatorname{Ln}(\text { Coal })+\beta_{7} \operatorname{Ln}(\text { Transport })+\alpha+\mu_{i}+\gamma_{t}+\varepsilon_{i t}
\end{aligned}
$$

where $i$ and $t$ refer to a specific province $i(i=1,2, \ldots, \mathrm{N})$, and a given time period $t(t=1,2, \ldots, \mathrm{T})$, respectively. $\rho$ is a parameter to be estimated. It is called the spatial autoregressive coefficient. $w$ is an element of the $N \times N$ non-negative spatial weights matrix describing the spatial structure of the spatial units, whose diagonal elements are set to zero. In this study, we employ a binary rook contiguity spatial weights matrix with the first order (henceforward noted as Rook-contiguity). The weights matrix is generally used in row-standardized form. Spatial Econometrics provides little theoretical foundations to specify the spatial weights matrix. Hence, to examine the robustness of the results based on the first-order rook-contiguity spatial weights matrix, we repeat the analysis by employing a four-nearest neighbors inverse-distance spatial weights matrix (using Euclidean distances between the provinces) (henceforward noted as four-nearest). $\beta_{1}, \beta_{2}, \beta_{3}, \beta_{4}, \beta_{5}, \beta_{6}, \beta_{7}$ are unknown parameters to be estimated. $\varepsilon$ is the error term. $\mu_{i}$ and $\gamma_{t}$ denote the spatial fixed effects and time-period fixed effects, respectively. Spatial fixed effects refer to controlling for all space-specific, time-invariant variables that are not included in the model. Time-period fixed effects refer to controlling for all time-specific, space-invariant variables that are not included in the model [16]. On the other hand, $\mu_{i}$ and $\gamma_{t}$ are treated as random variables that are independently and identically distributed with zero mean and variance $\sigma_{\mu}{ }^{2}$ and $\sigma_{\gamma}^{2}$, respectively. The random variables $\mu_{i}, \gamma_{t}$ and $\varepsilon_{i t}$ are independent of each other.

\subsubsection{Spatial Error Model}

The spatial error model assumes that the dependent variable is dependent on a set of observed explanatory variables, and the spatially autocorrelated error term. The spatial error model can be clearly defined as follows:

$$
\begin{aligned}
\operatorname{Ln}(E I)_{i t} & =\beta_{1} \operatorname{Ln}(G D P)_{i t}+\beta_{2} \operatorname{Ln}(\text { Second })_{i t}+\beta_{3} \operatorname{Ln}(F D I)_{i t}+\beta_{4} \operatorname{Ln}(\text { Trade })_{i t} \\
& +\beta_{5} \operatorname{Ln}(\text { Price })+\beta_{6} \operatorname{Ln}(\text { Coal })+\beta_{7} \operatorname{Ln}(\text { Transport })+\alpha+\mu_{i}+\gamma_{t}+\varepsilon_{i t} \\
\varepsilon_{i t} & =\lambda \sum_{j=1}^{N} w_{i j} \varepsilon_{i t}+v_{i t}
\end{aligned}
$$

where the change made to the Equation (2) is in the assumption regarding the spatially lagged error term instead of the spatially lagged dependent variable. $\lambda$ is usually called the spatial autocorrelation coefficient. All other variables are the same as Equation (2).

\subsubsection{Spatial Durbin Model}

One weakness of the two spatial regression models mentioned above, namely, the spatial lag model and the spatial error model, is that the dependent variable in the models may be explained not only by a spatially lagged dependent variable or spatially autocorrelated error term, but also by a spatially lagged dependent variable as well as spatially lagged independent variables combined together [17]. The best solution hence seems that both spatially lagged dependent variables and spatially lagged independent variables need to be included in the model, which then forms a new spatial model specification, namely, the spatial Durbin model.

We consider the spatial Durbin model specification due to the fact that the cost of ignoring spatial dependence among exogenous variables is rather high. From a practical point of view, there are two advantages to applying the spatial Durbin model. One advantage is that it produces unbiased and 
inconsistent estimates. The other one is that it does not necessarily impose prior restrictions on the magnitude of potential spatial spillover effects [18].

The spatial Durbin model exhibits an analogy to the spatial lag model. It reads:

$$
\begin{aligned}
\operatorname{Ln}(E I)_{i t} & =\rho \sum_{j=1}^{N} w_{i j} \operatorname{Ln}(E I)_{i t}+\beta_{1} \operatorname{Ln}(G D P)_{i t}+\beta_{2} \operatorname{Ln}(\text { Second })_{i t}+\beta_{3} \operatorname{Ln}(\text { FDI })_{i t}+\beta_{4} \operatorname{Ln}(\text { Trade })_{i t} \\
& +\beta_{5} \operatorname{Ln}(\text { Price })+\beta_{6} \operatorname{Ln}(\text { Coal })+\beta_{7} \operatorname{Ln}(\text { Transport }) \\
& +\beta_{8} \sum_{j=1}^{N} w_{i j} \operatorname{Ln}(\text { GDP })_{i t}+\beta_{9} \sum_{j=1}^{N} w_{i j} \operatorname{Ln}(\text { Second })_{i t}+\beta_{10} \sum_{j=1}^{N} w_{i j} \operatorname{Ln}(\text { FDI })_{i t}+\beta_{11} \sum_{j=1}^{N} w_{i j} \operatorname{Ln}(\text { Trade })_{i t} \\
& +\beta_{12} \sum_{j=1}^{N} w_{i j} \operatorname{Ln}(\text { Price })+\beta_{13} \sum_{j=1}^{N} w_{i j} \operatorname{Ln}(\text { Coal })+\beta_{14} \sum_{j=1}^{N} w_{i j} \operatorname{Ln}(\text { Transport }) \\
& +\alpha+\mu_{i}+\gamma_{t}+\varepsilon_{i t}
\end{aligned}
$$

where the interaction terms of spatial weights matrix and exogenous variables are designed to calculate spatial spillover effects among the exogenous variables. All other variables are the same as Equations (2) and (3).

\subsubsection{Direct, Indirect and Spatial Spillover Effects}

One objective of applied spatial econometric studies is to test if spatial spillovers exist or not by using point estimates of spatial econometric regression models. However, this may result in erroneous conclusions [19]. A new method developed by LeSage and Pace [19] to calculate the direct and indirect or spatial spillover effects in response to changes in the exogenous variables. The spatial Durbin model (Equation (4)) can be rewritten in vector form below.

$$
Y=(I-\rho W)^{-1} \mu+(I-\rho W)^{-1}(X \beta+W X \theta)+(I-\rho W)^{-1} \varepsilon
$$

The matrix of partial derivatives of $Y$ with respect to the $k_{t h}$ exogenous variable of $X$ in unit 1 up to unit $N$ is represented as follows:

$$
\left[\frac{\partial Y}{\partial x_{1 k}} \cdots \frac{\partial Y}{\partial x_{N k}}\right]=(I-\rho W)^{-1}\left[\beta_{k} I_{N}+\theta_{k} W\right]
$$

The partial derivatives represent the effect of a change of a specific exogenous variable in a specific spatial location on the dependent variable of all other locations. The direct effect is defined by LeSage and Pace [19] as the average of the diagonal elements of the matrix on the right side of Equation (6), and the indirect effect as the average of either the row sums or column sums of the non-diagonal elements of the matrix. Based on the theory mentioned above, we calculate the direct and indirect effect of each exogenous variable in our study.

\subsection{Variables}

In this section, we introduce the dependent variable, namely, energy intensity, and exogenous variables.

\subsubsection{Energy Intensity}

Energy intensity is defined as the ratio of energy consumption to GDP or gross provincial product (henceforward noted as EI). It represents the energy used to produce a unit of national or provincial output. It is given below.

$$
E I_{i t}=\frac{E C_{i t}}{G D P_{i t}}
$$

where $E C_{i t}$ denotes the total amount of energy consumption of province $i$ in time $t$ and GDP is real gross provincial product in 1998 year constant prices.

We turn to a discussion of the explanatory variables. 


\subsubsection{Per Capita GDP (GDP)}

One explanation of energy intensity decline is economic development thanks to the increase of services and high technology industries [20]. The level of economic development can be represented by per capita GDP. It can influence energy intensity through different channels [7]. For example, rising economic level induces people to enhance their awareness of the environmental protection and resources limits. The report of "A better world for all" shows that higher income countries use energy more efficiently. As low income countries develop, they become more energy efficient given the same quantity of energy, then they can generate more goods and services [21]. This case applies to Chinese provinces. The provinces with high energy intensity are generally located in Northwest China, most of which are economically lagged. However, the economically developed provinces are dotted in eastern China, which are featured by low energy intensity.

However, there may be a negative effect of the increase of income levels on energy intensity. This is because higher per capita income results in more and more consumption of energy intensive products like cars, air conditioners, central heating, etc. As a consequence, the increase of income leads to more energy use, and thereby drives energy intensity up. On the other hand, given one's consumption bundle, a higher income makes it possible for consumers to purchase more energy efficient products like electric and efficient cars. The net outcome may be ambiguous. However, higher income also has an impact on people's environmental awareness which in turn results in an increased demand for environmental protection [22,23]. Furthermore, provinces with higher income levels tend to expend more on environmental research and the adoption of clean and efficient technologies [24,25]. Wu [26] indicates that energy efficiency generally improves as an economy develops in China. Hence, we hypothesize that the growing per capita GDP can reduce energy intensity. Per capita GDP is expressed in 1998 year constant prices.

\subsubsection{The Share of the Secondary Sector (Second)}

In China, despite the secondary industrial sectors being widely recognized as energy intensive and low value-added; they remain the main pillars of the Chinese economy. For the mere goal of rapid economic growth, governments are encouraged to establish industrial parks to attract the industrial sectors. Behind such economic boom, a great deal of energy is consumed by the secondary industrial sectors in China, accounting for about $70 \%$ of total primary energy use [27]. The high share of the secondary industry is a major contributor to high energy intensity. It is therefore hypothesized that increase in the share of the secondary industry leads to increase in energy intensity.

\subsubsection{Foreign Direct Investment (FDI)}

Sit [28] argues that FDI has offered a substantial impetus in modernizing China's existing industrial systems, including the transfer of advanced technologies and managerial expertise. FDI creates technological externalities and knowledge spillovers [29]. FDI inflows are contributors to enhancing the existing level of technological knowledge through labor training, skills acquisition, and the introduction and adoption of management practices as well as advanced technologies [30-33]. Hence, FDI can be treated as a main channel to transfer advanced technology from developed to developing countries [8]. Existing studies conclude that FDI is one of the most indispensable determinants that negatively affect energy intensity $[6,34,35]$. Specifically, Mielnik and Goldemberg [36] empirically study the relationship between the decrease of energy intensity and FDI inflows in 20 developing countries. The result shows that FDI has a significant and negative effect on energy intensity. Eskeland and Harrison [37] reveal that foreign firms are significantly more energy efficient in four developing countries because of using more energy-efficient technology and cleaner sources of energy. Cole [38] and Peterson [39] examine the impact of FDI on the diffusion of technologies affects energy intensity. A great deal of foreign investment flowing into China has resulted in significant technology spillovers and direct technological transfer, leading to a decline in energy 
intensity. Zheng et al. [40] confirm that FDI can reduce energy intensity of China. We also expect such a similar conclusion. FDI is defined as per capita FDI in this study.

\subsubsection{International Trade (Trade)}

Since 1978, China has launched a reform and opening-up policy. It started to participate in the international trading systems. Trade has two reasons for lowering energy the intensity of China. Imported advanced equipment is able to renew China's high energy intensive industrial systems. Import has been commonly recognized as a key vehicle to diffuse advanced technologies because they are usually embedded in imported products and equipment [8]. Consequently, it reduces the aggregate energy intensity of China. The other one is that China has to enhance its competitiveness of exporting low energy intensive products or services to compete with the green trade barriers by reducing energy intensity. The green trade barriers have become increasingly rigorous, as evidenced by the ever-growing prevalence of technical standards in the international trade [41]. Reduction in energy intensity is a prerequisite for Chinese firms. Hence, we hypothesize that trade has a negative effect on energy intensity. Trade is defined as the ratio of international trade to gross provincial product.

\subsubsection{Energy Price (Price)}

According to economic theory, energy price should reflect marginal value. It can be taken as a policy handle to signal energy resources scarcity in an order to mitigate environmental degradation and reduce energy intensity. However, energy prices have long been controlled by the government, although China's energy sector is experiencing the transition to a market-oriented sector [7]. We consider the energy prices variable in the model. It is hypothesized to have a negative impact on energy intensity. Energy price is denoted by the purchasing price indices for raw materials, fuels and power.

\subsubsection{The Share of Coal in the Energy Consumption Structure (Coal)}

Coal has long dominated in the primary energy consumption structure in China. It has accounted for approximately 70\% during the past two decades, which can hardly be changed in the short term [42]. Coal is regarded as a low efficient and dirty energy source. The high proportion of coal in energy composition is the main reason for higher energy intensity. In addition, China's environment has been worsening due to a substantial amount of coal use.

On the other hand, renewable energy is clean and efficient that can accelerate economic growth. This is because it softens the constraint of a country or a region $[43,44]$. Furthermore, if clean and efficient renewable energy is more widely used, benefits can be obtained for sustainable economic growth, and for environmental protection [45]. Energy consumption structure hence plays an important role in affecting China's energy intensity. Unfortunately, data of renewable energy is not available to us. In this study, we use the share of coal in the primary energy consumption to denote energy consumption structure. It is hypothesized to have a positive impact on energy intensity.

\subsubsection{Transport Sector (Transport)}

China's transport sector has been growing rapidly in recent years. Specifically, it is experiencing tremendous vehicle growth and a rapidly growing freight traffic [46], which leads to a large amount of crude oil. By now, it has been the largest and fastest growing consumer of oil, even larger than the industrial sector. In 2014, the transport sector accounted for nearly $40 \%$ of the total crude oil consumption. We hypothesize that the increase of transport sector drives energy intensity up. Transport is defined as the growth rate of freight traffic. 


\subsection{Data Sources}

The dataset used in this study is a panel of 29 Chinese provinces from 1998 to 2014. Data are mainly obtained from "China Statistical Yearbook" [47], "China Energy Statistical Yearbook" [48], and "China Industry Economy Statistical Yearbook" [49]. In addition, the data of FDI are obtained from the China Economic Database (CEIC). Because data for Tibet, Hainan, Hong Kong, Macau, and Taiwan is not available, these five provinces are not included in this study.

\section{Results}

To provide a specific insight into the spatial pattern of energy intensity, we use visualization technique to map the distribution for China's energy intensity in 2014. The map is given below.

Figure 1 portraits that low energy intensity is clustered in costal eastern provinces (e.g., Beijing, Tianjin, Jiangsu, Shanghai, Zhejiang, Fujian, and Guangdong) while high energy intensity clustered in Northern Provinces (e.g., Xinjiang, Qinghai, Gansu, Inner Mongolia, Ningxia and Shanxi) and Guizhou of Southwest province. The Provinces along Changjiang River (Sichuan, Chongqing, Hubei, Hunan, Jiangxi and Anhui) and Northeast provinces (Heilongjiang, Jilin and Liaoning) are characterized with the national average level.

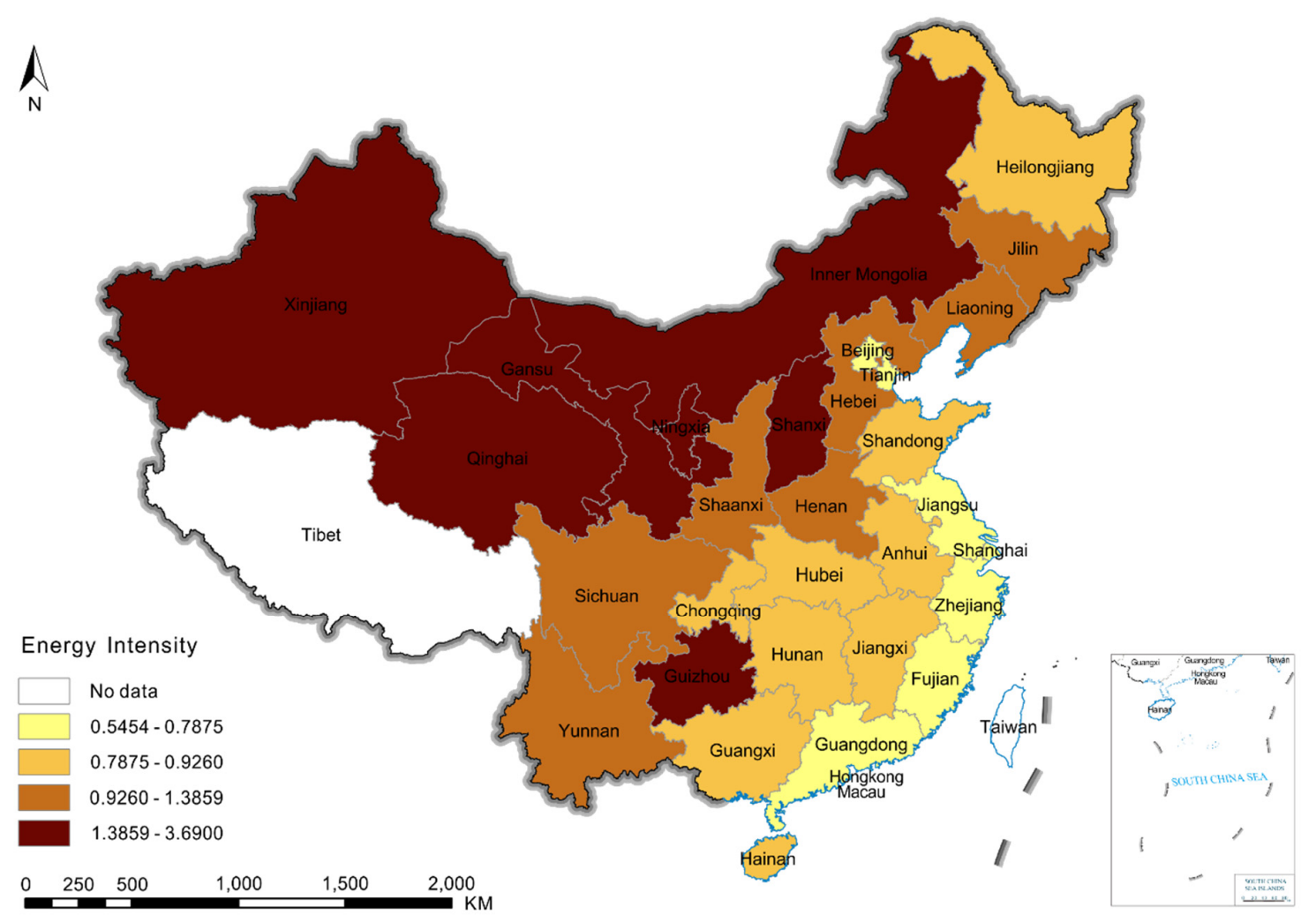

Figure 1. Spatial distribution for China's provincial energy intensity in 2014.

We turn to spatial regression analysis. Tests are required to examine whether spatially lagged dependent variable or spatially autocorrelated error term should be included in the model. The Lagrange Multiplier (LM) test and its equivalents: robust LM tests allow a distinction between spatial error models and spatial lag models. We test four model specifications, controlling for no fixed effects (Model 1), spatial fixed effects (Model 2), time-period fixed effects (Model 3) as well as spatial and time-period fixed effects (Model 4).

Table 1 reports the LM test results. In the context of no fixed effects and spatial fixed effects, both the hypothesis of no spatially lagged dependent variable and the hypothesis of no spatially 
autocorrelated error term are rejected at the $1 \%$ or $5 \%$ significance level when using LM tests. However, Robust LM statistics are in favor of spatial lag model. In contrast, in the context of time-period fixed effects, Robust LM statistics are in favor of the spatial error model. However, in the context of spatial and time-period, LM statistics cannot be rejected at the $10 \%$ significance level while Robust LM statistics results show that both the hypotheses of no spatially lagged dependent variable and the hypothesis of no spatially autocorrelated error terms can be rejected at the 5\% significance level. Obviously, both spatial lag model and spatial error model are not rejected.

Table 1. Tests for spatial dependence.

\begin{tabular}{|c|c|c|c|c|}
\hline Variable & Model 1 & Model 2 & Model 3 & Model 4 \\
\hline $\operatorname{Ln}(G D P)$ & $\begin{array}{c}-0.0155 \\
(-0.2366)\end{array}$ & $\begin{array}{l}-0.4322^{* * *} \\
(-12.7908)\end{array}$ & $\begin{array}{c}0.2684^{* * *} \\
(3.6007)\end{array}$ & $\begin{array}{l}-0.1459 * * \\
(-2.0390)\end{array}$ \\
\hline $\operatorname{Ln}($ Second $)$ & $\begin{array}{c}0.3022 * * * \\
(2.7020)\end{array}$ & $\begin{array}{l}0.8472 * * * \\
(13.3927)\end{array}$ & $\begin{array}{c}0.0844 \\
(0.7654)\end{array}$ & $\begin{array}{c}0.4443^{* * *} \\
(6.1838)\end{array}$ \\
\hline $\operatorname{Ln}(F D I)$ & $\begin{array}{c}-0.1401 \text { *** } \\
(-6.5537)\end{array}$ & $\begin{array}{l}-0.0210 * * \\
(-2.1113)\end{array}$ & $\begin{array}{c}-0.1526^{* * *} \\
(-7.3061)\end{array}$ & $\begin{array}{l}-0.0230 * * \\
(-2.5401)\end{array}$ \\
\hline Ln(Trade) & $\begin{array}{l}-0.0894^{* * *} \\
(-3.2823)\end{array}$ & $\begin{array}{c}0.0037 \\
(0.2110)\end{array}$ & $\begin{array}{c}-0.1975 * * * \\
(-6.5975)\end{array}$ & $\begin{array}{c}-0.0585^{* * *} \\
(-3.2614)\end{array}$ \\
\hline Ln(Price) & $\begin{array}{c}0.1061 \\
(0.9690)\end{array}$ & $\begin{array}{c}0.2881^{* * *} \\
(4.8268)\end{array}$ & $\begin{array}{c}0.8762 * * * \\
(4.6610)\end{array}$ & $\begin{array}{c}0.5836^{* * *} \\
(6.4126)\end{array}$ \\
\hline $\operatorname{Ln}($ Coal $)$ & $\begin{array}{c}0.2772 * * * \\
(4.8085)\end{array}$ & $\begin{array}{c}0.0386 \\
(0.9688)\end{array}$ & $\begin{array}{c}0.2035^{* * *} \\
(3.6106)\end{array}$ & $\begin{array}{c}-0.0494 \\
(-1.2661)\end{array}$ \\
\hline Ln(Transport) & $\begin{array}{c}-0.1194^{* * *} \\
(-2.9935)\end{array}$ & $\begin{array}{c}-0.0348 \\
(-1.5400)\end{array}$ & $\begin{array}{c}-0.0232 \\
(-0.5789) \\
\end{array}$ & $\begin{array}{l}0.0359 * \\
(1.6730)\end{array}$ \\
\hline Adjusted $\mathrm{R}^{2}$ & 0.5279 & 0.9580 & 0.5845 & 0.9672 \\
\hline Log Likelihood & -154.6280 & 438.0489 & -126.7124 & 498.8760 \\
\hline LM lag & $21.5178^{* * *}$ & $29.9868^{* * *}$ & 0.2714 & 0.2442 \\
\hline Robust LM lag & $8.0180 * * *$ & $25.6892 * * *$ & $4.0655^{* *}$ & $4.9754^{* *}$ \\
\hline LM error & $13.6086^{* * *}$ & $6.1974 * *$ & $7.4319^{* * *}$ & 0.0988 \\
\hline Robust LM error & 0.1087 & 1.8999 & $11.2260^{* * *}$ & $4.8300 * *$ \\
\hline
\end{tabular}

The choice of spatial regression models depends on controlling for spatial fixed effects or time-period fixed effects or both. To find out that the null hypothesis that the spatial fixed effects are jointly insignificant, we conduct an LR test. The results $(1251.1767, p<0.0001)$ indicate that the null hypothesis can be rejected at the 1\% significant level. Similarly, the null hypothesis of joint insignificance of time-period fixed effects is also strongly rejected $(121.6542, p<0.0001)$. Both test results justify controlling for two-way fixed effects, namely, spatial and time-period fixed effects. In addition to LR test, we also perform Hausman test, the hypothesis is strongly rejected. To sum up, we need to control for spatial and time-period fixed effects in the spatial regression models.

We now consider the spatial Durbin model specification.

Table 2 reports the results of the spatial Durbin model. The second column presents spatial and time-period fixed effects spatial Durbin model results by means of Rook-contiguity spatial weights matrix (Model 5). To test the hypothesis if the spatial Durbin model can be simplified to the spatial lag model, we perform both the Wald and LR tests. When using the Wald test $(102.6981, p<0.0001)$ and the LR test $(100.7323, p<0.0001)$, the results show that the null hypothesis is strongly rejected. Similarly, the null hypothesis if the spatial Durbin model can be simplified to the spatial error model can also be strongly rejected when using the Wald test $(107.9347, p<0.0001)$ and the LR test $(103.5826$, $p<0.0001)$. Similarly, the third column presents the spatial and time-period fixed effects spatial Durbin model by means of the four-nearest spatial weights matrix (Model 6). Test results show that the spatial 
lag model and spatial error model are strongly rejected. To sum up, the spatial Durbin model should be employed.

Table 2. Estimation results of the spatial and time-period fixed effects of the spatial Durbin model.

\begin{tabular}{|c|c|c|}
\hline Variable & Rook Contiguity (Model 5) & Four-Nearest (Model 6) \\
\hline $\operatorname{Ln}(G D P)$ & $0.0076(0.1072)$ & $-0.1059(-1.4799)$ \\
\hline $\operatorname{Ln}($ Second $)$ & $0.4341(6.1878)^{* * *}$ & $0.3616(4.7169)^{* * *}$ \\
\hline $\operatorname{Ln}(F D I)$ & $-0.0366(-4.0168) * * *$ & $-0.0281(-3.1434)^{* * *}$ \\
\hline Ln(Trade) & $-0.0529(-2.8094) * *$ & $-0.0789(-4.0788) * * *$ \\
\hline $\operatorname{Ln}($ Price $)$ & $0.5930(6.4074)^{* * *}$ & $0.6278(6.6743)^{* * *}$ \\
\hline $\operatorname{Ln}($ Coal $)$ & $-0.1504(-3.8618)^{* * *}$ & $-0.1752(-4.0296) * * *$ \\
\hline Ln(Transport) & $0.0010(0.0482)$ & $0.0465(2.0917) * *$ \\
\hline$W \times \operatorname{Ln}(G D P)$ & $-0.1889(-1.2790)$ & $-0.0488(-0.7802)$ \\
\hline$W \times \operatorname{Ln}($ Second $)$ & $0.6369(4.3118)^{* * *}$ & $0.3556(2.8183) * * *$ \\
\hline$W \times \operatorname{Ln}(F D I)$ & $-0.1436(-6.7544)^{* * *}$ & $-0.0535(-2.5948) * * *$ \\
\hline$W \times \operatorname{Ln}($ Trade $)$ & $0.0787(2.0040) * *$ & $-0.0293(-1.0121)$ \\
\hline$W \times \operatorname{Ln}($ Price $)$ & $-0.3375(-1.5485)$ & $-0.1720(-1.8505) *$ \\
\hline$W \times \operatorname{Ln}($ Coal $)$ & $0.2709(3.1055)^{* * *}$ & $-0.1439(-1.9813)^{* *}$ \\
\hline$W \times \operatorname{Ln}($ Transport $)$ & $0.0951(2.1958) * *$ & $0.0071(0.1763)$ \\
\hline$\rho$ & $0.0110(0.1770)$ & $-0.1446(-3.1556) * * *$ \\
\hline Adjusted $\mathrm{R}^{2}$ & 0.3684 & 0.2900 \\
\hline Log Likelihood & 550.81605 & 523.50563 \\
\hline Wald test spatial lag & $102.6981^{* * *}$ & $65.8544^{* * *}$ \\
\hline LR test spatial lag & $100.7323^{* * *}$ & $52.6266^{* * *}$ \\
\hline $\begin{array}{c}\text { Wald test spatial } \\
\text { error }\end{array}$ & $107.9347^{* * *}$ & $50.5973^{* * *}$ \\
\hline LR test spatial error & $103.5826^{* * *}$ & $49.1485^{* * *}$ \\
\hline
\end{tabular}

Notes: $t$-statistics in parenthesis. ${ }^{*}: p<0.10^{* *}: p<0.05,{ }^{* * *}: p<0.01$.

By comparing the two model results, we find out that adjusted $R^{2}(0.3684)$ of Model 5 is larger than that (0.2900) of Model 6. In addition, Log Likelihood (550.81605) of Model 5 can also be found to be larger than that (523.50563) of Model 6. To sum up, Model 5 is a better fitted model. Although both Wald and LR test results are in favor of two spatial Durbin models, the most important parameter, the spatial autoregressive coefficient, in the case of spatial Durbin model by means of Rook-contiguity spatial weights matrix (Model 5), is highly insignificant. Below, an analysis hence proceeds based on the spatial Durbin model with the four-nearest spatial weights matrix (Model 6).

From the results of Model 6, all variables are significant at the 1\%, 5\% or 10\% significance level, except $L n(G D P), W \times L n(G D P), W \times L n$ (Trade), and $W \times L n$ (Transport). $L n(G D P)$ and $W \times L n(G D P)$ are negative in line with our expectations, but they are insignificant. $\operatorname{Ln}($ Second) and $W \times \operatorname{Ln}($ Second) are positive and highly significant, indicating that the secondary industry in a province and in its neighboring provinces drives energy intensity up. $L n(F D I)$ and $W \times L n(F D I)$, in line with expectations, are negative and significant, indicating that FDI have a significant negative effect on energy intensity, and that spatial spillover effects of FDI work well. $L n$ (Trade) and $W \times L n$ (Trade) have negative effects on energy intensity, indicating that trade is an effective channel to lower energy intensity. Ln(Price) is surprisingly positive and significant while $W \times L n($ Price $)$ is significantly negative. $L n($ Coal) and $W \times \operatorname{Ln}($ Coal) are significantly negative, not in line with our expectations. One possible explanation is that this indicator may not be a good proxy indicator for the share of coal in the energy consumption structure. $L n$ (Transport) is significant and positive, in line with expectations.

Analyses based on point estimates of the spatial Durbin model discussed above may lead to erroneous conclusions. We thereby turn to the discussion on direct, indirect and total effects.

Table 3 reports the direct, indirect and total effects of the explanatory variables and their associated $t$ statistics in the two spatial Durbin models with the four-nearest and Rook contiguity spatial weights 
matrix. Combined with the results, we focus on their implications. An analysis of direct and indirect effects of the explanatory variables based on the four-nearest spatial weights matrix is discussed below.

Table 3. Direct, indirect and total effects.

\begin{tabular}{|c|c|c|c|c|}
\hline Spatial Weights & Variable & Direct Effect & Indirect Effect & Total Effect \\
\hline \multirow{7}{*}{ Four-nearest } & $\operatorname{Ln}(G D P)$ & $\begin{array}{c}-0.1012 \\
(-1.4285)\end{array}$ & $\begin{array}{c}-0.0318 \\
(-0.5284)\end{array}$ & $\begin{array}{l}-0.1330 * \\
(-1.7600)\end{array}$ \\
\hline & Ln(Second) & $\begin{array}{c}0.3424^{* * *} \\
(4.4914)\end{array}$ & $\begin{array}{l}0.2887 * * \\
(2.5393)\end{array}$ & $\begin{array}{c}0.6312 * * * \\
(4.4249)\end{array}$ \\
\hline & $\operatorname{Ln}(F D I)$ & $\begin{array}{c}-0.0256^{* * *} \\
(-2.7510)\end{array}$ & $\begin{array}{l}-0.0458^{* *} \\
(-2.3442)\end{array}$ & $\begin{array}{c}-0.0714^{* * *} \\
(-3.5250)\end{array}$ \\
\hline & Ln(Trade) & $\begin{array}{c}-0.0781^{* * *} \\
(-3.9468)\end{array}$ & $\begin{array}{c}-0.0174 \\
(-0.6511)\end{array}$ & $\begin{array}{c}-0.0955^{* * *} \\
(-2.9218)\end{array}$ \\
\hline & Ln(Price) & $\begin{array}{c}0.6491 * * * \\
(7.0180)\end{array}$ & $\begin{array}{c}-0.2455^{* * *} \\
(-2.6436)\end{array}$ & $\begin{array}{c}0.4036^{* * *} \\
(3.3038)\end{array}$ \\
\hline & $\operatorname{Ln}($ Coal $)$ & $\begin{array}{c}-0.1689 * * * \\
(-3.8127)\end{array}$ & $\begin{array}{l}-0.1133 * \\
(-1.6527)\end{array}$ & $\begin{array}{c}-0.2822 * * * \\
(-3.3263)\end{array}$ \\
\hline & Ln(Transport) & $\begin{array}{l}0.0463 * \\
(1.9792)\end{array}$ & $\begin{array}{c}-0.0002 \\
(-0.0060)\end{array}$ & $\begin{array}{c}0.0460 \\
(1.2417)\end{array}$ \\
\hline \multirow{7}{*}{ Rook contiguity } & $\operatorname{Ln}(G D P)$ & $\begin{array}{c}0.0089 \\
(0.1249)\end{array}$ & $\begin{array}{c}-0.1893 \\
(-1.2046)\end{array}$ & $\begin{array}{c}-0.1804 \\
(-1.0341)\end{array}$ \\
\hline & $\operatorname{Ln}($ Second $)$ & $\begin{array}{c}0.4335^{* * *} \\
(6.1859)\end{array}$ & $\begin{array}{c}0.6444^{* * *} \\
(4.2187)\end{array}$ & $\begin{array}{l}1.0779 * * * \\
(6.3163)\end{array}$ \\
\hline & $\operatorname{Ln}(F D I)$ & $\begin{array}{c}-0.0367^{* * *} \\
(-4.0603)\end{array}$ & $\begin{array}{l}-0.1456^{* * *} \\
(-6.3676)\end{array}$ & $\begin{array}{c}-0.1823^{* * * *} \\
(-6.8081)\end{array}$ \\
\hline & Ln(Trade) & $\begin{array}{l}-0.0528^{* * *} \\
(-2.8123)\end{array}$ & $\begin{array}{l}0.0790 * \\
(1.9716)\end{array}$ & $\begin{array}{c}0.0262 \\
(0.5786)\end{array}$ \\
\hline & Ln(Price) & $\begin{array}{c}0.5913 * * * \\
(6.2329)\end{array}$ & $\begin{array}{c}-0.3340 \\
(-1.5149)\end{array}$ & $\begin{array}{c}0.2573 \\
(1.0339)\end{array}$ \\
\hline & $\operatorname{Ln}($ Coal $)$ & $\begin{array}{c}-0.1489 * * * \\
(-3.8173)\end{array}$ & $\begin{array}{c}0.2675 * * * \\
(2.9484)\end{array}$ & $\begin{array}{c}0.1186 \\
(1.2777) \\
\end{array}$ \\
\hline & Ln(Transport) & $\begin{array}{c}0.0006 \\
(0.0290)\end{array}$ & $\begin{array}{l}0.0976^{* *} \\
(2.1227)\end{array}$ & $\begin{array}{l}0.0982 * * \\
(2.1356)\end{array}$ \\
\hline
\end{tabular}

Notes: $t$-statistics in parenthesis. ${ }^{*}: p<0.10,{ }^{* *}: p<0.05,{ }^{* * *}: p<0.01$.

The direct and indirect effects are of greater interest for us to determine whether the spatial spillover effects of exogenous variables exist and find out the implications of the parameters estimated in the context of spatial Durbin model specification. Regarding signs, direct and indirect effects of the seven explanatory variables are overall in line with the results of the spatial Durbin model.

The findings show that the direct and indirect effects of GDP are negative, also in line with expectations, but insignificant. However, the total effect of GDP is significantly negative, indicating that the rise of per capita GDP will reduce energy intensity. The OECD Environment Directorate [50] asserts that energy intensity can assess environmental performance because it reflects not only changes in energy efficiency but also efforts to reduce energy consumption and improve environmental quality. As income level goes up, people are increasingly demanding a good environment and aware of the indicator of energy intensity, and of energy saving.

Many empirical studies have verified that economic growth is closely correlated with energy consumption. For example, Ajmi et al. [51] study the causal links between energy consumption and national income in G7 countries. Akinlo [52] examines the energy-GDP links for 11 countries in Sub-Saharan Africa. Economic growth is an important factor impacting energy consumption. On the 
other hand, Energy consumption could have an impact on per capita GDP. Narayan [53] verifies that in the context of 32 lower middle-income countries, per capita energy consumption predicts per capita real GDP. Narayan's 2016 study [53] provides future policy directions and offers us a new perspective to test the links between economic growth and energy consumption.

Besides, since pollution diffuses across borders: an environmentally friendly province requires its polluted provinces to reduce their energy intensity. In return, people living in polluted provinces complain about deteriorated environment, and further require a good eco-environment because their neighboring provinces have a good environment.

The direct effect and indirect effect of the share of the secondary sectors amount to 0.3424 and 0.2824 , respectively. The share of the secondary sectors of a province strongly affect both local energy intensity (elasticity 0.3424 ) and its neighboring energy intensity (elasticity 0.2824 ). In China, the local governments regard the secondary sector as catalyst for local economic growth although the secondary industry is notorious for high energy intensity and low value-added. With the goal of GDP growth, the governments tend to establish industrial parks to introduce industrial sector. This is a major reason why local energy intensity remains high. The economic success of a province by increasing the secondary sector sets a "good" example for its neighboring provinces. They easily follow this sort of economic pattern. The higher proportion of the secondary sectors to local economies deteriorates energy intensity.

In view of $F D I$, its significant direct effect is -0.0256 and indirect effect -0.0458 . FDI can not only bring advanced technologies and equipment, but can also create technological externalities or knowledge spillovers. However, the advantages have not been significantly seen in recipient provinces. Fortunately, knowledge spillovers diffuse and are captured by neighboring provinces. Foreign firms operating in their own provinces are generally energy efficient and use clean energy. Their products in recipient provinces can stimulate local firms to create innovation and thus help renew processes. FDI generates demonstration effects that can be captured by recipient provinces and neighborhoods. The domestic firms in neighboring provinces are forced to adopt new energy efficient equipment and innovate their products for competition, which leads to reducing energy intensity.

As shown in Table 3, the direct effect of the Trade variable amounts to -0.0781 , indicating that trade within one's own province has a negative effect on local energy intensity. The indirect effect of Trade of a province on energy intensities of neighboring provinces amounts to -0.0174 (highly insignificant). Imports of advanced products are attributed to energy intensity reduction of recipient provinces. Herrerias et al. [8] find that China develops its innovation strategy by combing imports of technology with domestic R\&D.

The direct effect of Price variable is significantly positive. One possible explanation is that the rise of energy prices stimulates stock energy in a bid to avoid the ever-growing energy costs. However, a substantial amount of energy stock encourages extravagant and wasteful consumption. Energy intensity thereby increases. The indirect effect of the Price variable is significantly negative, indicating that when energy prices rise in neighboring provinces, a province cannot get access to cheap energy from neighboring provinces, which stimulates it to save energy consumption and then drives energy intensity down.

The direct and indirect effects of the Coal variable are surprisingly significant and negative, indicating that the rise of the share of coal in the energy consumption structure lowers energy intensity, which is not in line with our expectations. One possible explanation is that the indicator may not be a good proxy to reflect the share of coal in the energy consumption structure. This could be due to the fact that we used the aggregated coal data, and could not separate the different types of coal in the study.

Last but not the least, we still focus on the Transport variable. The direct effect of the Transport variable is significant and positive, indicating that the growing transport sector drives energy intensity up. However, the indirect effect of the Transport variable is insignificant, and negative not in line with expectations. 


\section{Conclusions}

This paper concludes with a discussion of determinants of energy intensity. The analytic results from the spatial Durbin model is hereby the first attempt to explore the determinants for the current status of energy intensity in China with the inclusion both spatially lagged dependent variables and independent variables. One advantage of this study is to provide a unique approach to explore this complicated problem from a spatial perspective. The main findings of this study and their associated implications are relatively thought-provoking and profound. They may help to re-guide nationwide and local policy-making in terms of energy intensity reduction and energy saving in the condition of energy shortage and environmental degradation. The spatial approach is expected to provide new insights which may lead to better energy policy making, energy use planning, professional management of sectors and appropriate regional energy consumption as well.

China's great demand for primary energy is intensive because of continuous economic growth in the whole nation. However, regionally, the issue has long been complicated by the dichotomy of the rapid economic development stage and energy intensity. In relation to energy intensity, its geographical distribution in China is immensely unbalanced over space. The eastern provinces along the coastal line are energy efficient, leading the national economy. High economic level means more energy efficient modern industrial systems and advanced technologies. Their neighboring low-energy-efficient provinces also can introduce management experience or expertise and import equipment by purchase from eastern provinces for reducing energy intensity.

Unsurprisingly, the rise in the share of the secondary industry leads to an increase in energy intensity in a province. Although the industrial sectors are energy intensive and low value-added, they remain the major pillars of the economy of a province. For the mere goal of economic growth, governments are encouraged to establish industrial parks to attract the industrial sectors. They set a "good" example for its neighborhood. The neighboring provinces easily follow the economic pattern. Consequently, energy intensity goes up. Although China has already been dependent on the secondary industry in the process of acceleration of industrialization, we must be aware of the newly emerging tertiary industries. The tertiary sectors, which are high-value-added and energy-efficient, can be considered as an effective approach to reduce energy intensity in the future. However, the solution to lowering energy efficiency is not easy or straightforward merely because of the industrial restructuring, upgrade, and transfer involved for China. A more sophisticated and clear-cut national plan of coordinating nationwide industrial restructuring, upgrade, and transfer needs to be considered.

In the case of China, technological progress is absolutely an important catalyst to stimulate the transformation of the old-fashioned, low-energy-efficient industries to the newly-built, high-energy-efficient, and environmentally friendly ones. New energy policies towards a wide and rapid adoption of clean and renewable energy and energy saving technologies are needed. Moreover, R\&D on environmental protection in both national research institutions and firms also needs to be encouraged. Deep reforms are urgently needed to directly and widely transfer new technologies and management practices from advanced economies to China. In addition, domestic independent innovation should be emphasized and encouraged. FDI inflows with advanced technologies and in-house R\&D can interact with each other to create substantial energy-saving effects. FDI contributes to the energy saving effects of in-house R\&D; in return in-house R\&D enhances the energy-saving impact of FDI [34]. Their integration can help China realize the goal of reduction in energy intensity implemented by the government. In addition, new types of energy research and development and advanced energy technologies should be financially subsidized by local governments, and even the Chinese central government in a bid to support the successful incubation of a different system of energy industries.

The export-oriented Chinese economy depends heavily on international trade. On the one side, China imports comparatively advanced equipment in international trading systems and catches up with technological updates. The eastern provinces dotted along the coastal line have the geographical advantage. They benefit from imports regarding both economic growth and energy intensity reduction. 
Imported advanced technologies should also be seized upon by neighborhoods of eastern provinces to reduce energy intensity. On the other hand, the rapid economic growth of China is attributed to exports. Facing international competition, Chinese firms have to produce and export low energy intensive products because of increasing green barriers. In addition, Chinese governments should implement policies to discourage the export of such energy intensive products as primary products.

Author Contributions: Lei Jiang conceived the entire paper, analyzed the data, estimated the spatial Durbin model and spatial spillover effects, and wrote the paper. Minhe Ji provided technique support and polished the text of the paper.

Conflicts of Interest: The authors declare no conflict of interest.

\section{References}

1. Yang, L.; Yang, T. Energy consumption and economic growth from perspective of spatial heterogeneity: Statistical analysis based on variable coefficient model. Ann. Oper. Res. 2015, 228, 151-161. [CrossRef]

2. Zhao, X.; Ma, C.; Hong, D. Why did China's energy intensity increase during 1998-2006: Decomposition and policy analysis. Energy Policy 2010, 38, 1379-1388. [CrossRef]

3. The Eleventh Five-Year Plan for National Economic and Social Development of the People's Republic of China. Available online: http://www.npc.gov.cn/wxzl/gongbao/2006-03/18/content_5347869.htm (accessed on 14 March 2006). (In Chinese)

4. Wang, X. On China's energy intensity statistics: Toward a comprehensive and transparent indicator. Energy Policy 2011, 39, 7284-7289. [CrossRef]

5. The Twelfth Five-Year Plan for National Economic and Social Development of the People's Republic of China. Available online: http://www.gov.cn/2011lh/content_1825838.htm (accessed on 16 March 2011). (In Chinese)

6. Hang, L.; Tu, M. The impacts of energy prices on energy intensity: Evidence from China. Energy Policy 2007, 35, 2978-2988. [CrossRef]

7. Song, F.; Zheng, X. What drives the change in China's energy intensity: Combining decomposition analysis and econometric analysis at the provincial level. Energy Policy 2012, 51, 445-453. [CrossRef]

8. Herrerias, M.J.; Cuadros, A.; Orts, V. Energy intensity and investment ownership across Chinese provinces. Energy Econ. 2013, 36, 286-298. [CrossRef]

9. Yu, H. The influential factors of China's regional energy intensity and its spatial linkages: 1988-2007. Energy Policy 2012, 45, 583-593. [CrossRef]

10. Greene, W.H. Econometric Analysis, 5th ed.; Pearson Education: Upper Saddle River, NJ, USA, 2005.

11. Yuxiang, K.; Chen, Z. Government expenditure and energy intensity in China. Energy Policy 2010, 38, 691-694. [CrossRef]

12. Sadorsky, P. Do urbanization and industrialization affect energy intensity in developing countries? Energy Econ. 2013, 37, 52-59. [CrossRef]

13. Blumsack, S.; Xu, J. Spatial variation of emissions impacts due to renewable energy siting decisions in the Western US under high-renewable penetration scenarios. Energy Policy 2011, 39, 6962-6971. [CrossRef]

14. Douglas, S.M.; Popova, J.N. Econometric estimation of spatial patterns in electricity prices. Energy J. 2011, 32 , 81-106. [CrossRef]

15. Elhorst, J.P. Specification and estimation of spatial panel data models. Int. Reg. Sci. Rev. 2003, 26, $244-268$. [CrossRef]

16. Baltagi, B. Econometric Analysis of Panel Data, 3rd ed.; John Wiley \& Sons: Chichester, UK, 2005.

17. Manski, C.F. Identification of endogenous social effects: The reflection problem. Rev. Econ. Stud. 1993, 60, 531-542. [CrossRef]

18. Elhorst, J.P. Applied spatial econometrics: Raising the bar. Spat. Econ. Anal. 2010, 5, 9-28. [CrossRef]

19. LeSage, J.; Pace, R.K. Introduction to Spatial Econometrics; CRC Press: Boca Raton, FL, USA, 2009.

20. Destais, G.; Fouquau, J.; Hurlin, C. Economic development and energy intensity: A panel data analysis. In The Econometrics of Energy Systems; Palgrave Macmillan: Basingstoke, UK, 2007.

21. A Better World for All. Available online: https://www.imf.org/external/pubs/ft/jointpub/world/2000/ eng/bwae.pdf (accessed on 26 June 2000). 
22. Suri, V.; Chapman, D. Economic growth, trade and energy: Implications for the environmental Kuznets curve. Ecol. Econ. 1998, 25, 195-208. [CrossRef]

23. Dinda, S. Environmental Kuznets curve hypothesis: A survey. Ecol. Econ. 2004, 49, 431-455. [CrossRef]

24. Komen, M.H.; Gerking, S.; Folmer, H. Income and environmental R\&D: Empirical evidence from OECD countries. Environ. Dev. Econ. 1997, 2, 505-515.

25. Stern, D.I. The rise and fall of the environmental Kuznets curve. World Dev. 2004, 32, 1419-1439. [CrossRef]

26. Wu, Y. Energy intensity and its determinants in China's regional economies. Energy Policy 2012, 41, 703-711. [CrossRef]

27. Liao, H.; Fan, Y.; Wei, Y.M. What induced China's energy intensity to fluctuate: 1997-2006? Energy Policy 2007, 35, 4640-4649. [CrossRef]

28. Sit, V.F. The special economic zones of China: A new type of export processing zone? Dev. Econ. 1985, 23, 69-87. [CrossRef]

29. Markusen, J.R.; Venables, A.J. Foreign direct investment as a catalyst for industrial development. Eur. Econ. Rev. 1999, 43, 335-356. [CrossRef]

30. Cuadros, A.; Orts, V.; Alguacil, M. Openness and growth: Re-examining foreign direct investment, trade and output linkages in Latin America. J. Dev. Stud. 2004, 40, 167-192. [CrossRef]

31. Kugler, M. Spillovers from foreign direct investment: Within or between industries? J. Dev. Econ. 2006, 80, 444-477. [CrossRef]

32. Blalock, G.; Gertler, P.J. Welfare gains from foreign direct investment through technology transfer to local suppliers. J. Int. Econ. 2008, 74, 402-421. [CrossRef]

33. Alguacil, M.; Cuadros, A.; Orts, V. Inward FDI and growth: The role of macroeconomic and institutional environment. J. Pol. Model. 2011, 33, 481-496. [CrossRef]

34. Fisher-Vanden, K.; Jefferson, G.H.; Jingkui, M.; Jianyi, X. Technology development and energy productivity in China. Energy Econ. 2006, 28, 690-705. [CrossRef]

35. Doytch, N.; Narayan, S. Does FDI influence renewable energy consumption? An analysis of sectoral FDI impact on renewable and non-renewable industrial energy consumption. Energy Econ. 2015, 54, 291-301. [CrossRef]

36. Mielnik, O.; Goldemberg, J. Foreign direct investment and decoupling between energy and gross domestic product in developing countries. Energy Policy 2001, 30, 87-89. [CrossRef]

37. Eskeland, G.S.; Harrison, A.E. Moving to greener pastures? Multinationals and the pollution haven hypothesis. J. Dev. Econ. 2003, 70, 1-23. [CrossRef]

38. Cole, M.A. Does trade liberalization increase national energy use? Econ. Lett. 2006, 92, 108-112. [CrossRef]

39. Peterson, S. Greenhouse gas mitigation in developing countries through technology transfer? A survey of empirical evidence. Mitig. Adapt. Strat. Glob. Chang. 2008, 13, 283-305. [CrossRef]

40. Zheng, Y.; Qi, J.; Chen, X. The effect of increasing exports on industrial energy intensity in China. Energy Policy 2011, 39, 2688-2698. [CrossRef]

41. Mold, A. Non-Tariff Barriers: Their Prevalence and Relevance for African Countries; African Trade Policy Centre: Addis Ababa, Ethiopia, 2005.

42. Feng, T.; Sun, L.; Zhang, Y. The relationship between energy consumption structure, economic structure and energy intensity in China. Energy Policy 2009, 37, 5475-5483. [CrossRef]

43. Magnani, N.; Vaona, A. Regional spillover effects of renewable energy generation in Italy. Energy Policy 2013, 56, 663-671. [CrossRef]

44. Vaona, A. The effect of renewable energy generation on import demand. Renew. Energy 2016, 86, 354-359. [CrossRef]

45. Kaygusuz, K. Energy for sustainable development: Key issues and challenges. Energy Sourc. B Energy Econ. Plan. 2007, 2, 73-83. [CrossRef]

46. Wu, L.; Huo, H. Energy efficiency achievements in China's industrial and transport sectors: How do they rate? Energy Policy 2014, 73, 38-46. [CrossRef]

47. National Bureau of Statistics of China (NBSC). China Energy Statistical Yearbook 2015; China Statistics Press: Beijing, China, 2015. (In Chinese)

48. National Bureau of Statistics of China (NBSC). China Statistical Yearbook 2015; China Statistics Press: Beijing, China, 2015. (In Chinese) 
49. National Bureau of Statistics of China (NBSC). China Industry Economy Statistical Yearbook 2015; China Statistics Press: Beijing, China, 2015. (In Chinese)

50. OECD Key Environmental Indicators. Available online: https://www.oecd.org/env/indicators-modellingoutlooks/37551205.pdf (accessed on 20 April 2004).

51. Ajmi, A.N.; Montasser, G.E.; Nguyen, D.K. Testing the relationships between energy consumption and income in G7 countries with nonlinear causality tests. Econ. Model. 2013, 35, 126-133. [CrossRef]

52. Akinlo, A.E. Energy consumption and economic growth: Evidence from 11 sub-Sahara African countries. Energy Econ. 2008, 30, 2391-2400. [CrossRef]

53. Narayan, S. Predictability within the energy consumption-economic growth nexus: Some evidence from income and regional groups. Econ. Model. 2016, 54, 515-521. [CrossRef]

(C) 2016 by the authors; licensee MDPI, Basel, Switzerland. This article is an open access article distributed under the terms and conditions of the Creative Commons Attribution (CC-BY) license (http://creativecommons.org/licenses/by/4.0/). 